Article

\title{
What is Smart for the Future City? Mobilities and Automation
}

\author{
Malene Freudendal-Pedersen ${ }^{1}$, Sven Kesselring ${ }^{2, *}$ a and Eriketti Servou ${ }^{3}($ ) \\ 1 Department of Planning, Aalborg University, 9000 Aalborg, Denmark; mfp@plan.aau.dk \\ 2 Faculty of Economics and Law, Nürtingen-Geislingen University, 73312 Geislingen, Germany \\ 3 mobil.LAB Doctoral Research Group, Chair of Urban Structure and Transport Planning \& Munich Center for \\ Technology in Society (MCTS); Technical University Munich, 80333 Munich, Germany; \\ eriketti.servou@tum.de \\ * Correspondence: Sven.Kesselring@hfwu.de; Tel.: +49-7331-22525
}

Received: 26 November 2018; Accepted: 14 December 2018; Published: 4 January 2019

check for updates

\begin{abstract}
Cities have changed their pulse, their pace, and reach, and the urban scale is an interconnected element of the global "network society" with new forms of social, cultural and economic life emerging. The increase in the amount and speed of mobilities has strong impacts on ecological conditions, and, so far, no comprehensive sustainable solutions are in sight. This paper focuses on the discussion around smart cities, with a specific focus on automation and sustainability. Discourses on automated mobility in urban spaces are in a process of creation and different stakeholders contribute in shaping the urban space and its infrastructures for automated driving in the near or distant future. In many ways, it seems that the current storylines, to a high degree, reinforce and (re)produce the "system of automobility". Automobility is still treated as the iconic and taken-for-granted form of modern mobility. It seems that most actors from industry, planning, and politics consider it as being sustained through smart and green mobility innovations and modifications. The paper discusses the implication of these techno-policy discourses and storylines for urban planning. It presents preliminary results from ongoing research on policy promotion strategies of automated driving in the region of Munich, Germany.
\end{abstract}

Keywords: mobilities; smart cities; sustainability; discourses; automated driving; Munich

\section{Introduction}

In today's cities and regions, multiple mobilities—social, technological, geographic, cultural and digital-are at the core of new types of socio-material and cultural relationships and shape people's everyday lives and businesses in many ways [1,2]. The rapidly moving technological developments in transportation and communication have changed cities' pulses, their pace, and reach. The urban scale is thereby an interconnected element of the global "network society" [3,4], with new forms of social, cultural, and economic life emerging. This increase in the amount and speed of mobilities has strong impacts on ecological conditions, and, so far, no comprehensive sustainable solutions are in sight [5]. The overarching role of mobility and transportation in modern societies has generated a fast growing field of social-science-based mobilities research. This rising field focuses on large-scale as well as regional movements of people, goods, capital, and information [6-8]. The cross-fertilization of disciplines and academic traditions in this field brings about strong and innovative approaches concerning the future of cities that integrate the human as well as the systematic and the global scale of current transformations [9-12].

Today, we live in a highly mobilized and globalized "risk society" $[13,14]$. The theoretical concept of the "mobile risk society" [15] frames a way of combining key elements from the "theory of reflexive 
modernization" [16] and the "new mobilities paradigm" [9]. It is defined as a systematic way of dealing with the risks, insecurities, uncertainties, and unintended side effects that are induced by the technological and organizational modernization of mobility and transportation. Modern societies do not have increased risks per se. Nevertheless, more saliently, what has changed is the character of risks and the mode of societal observation and perception. Due to increased mobilities, "perceived" (global) risks, such as climate change, economic and financial crises, the global unsustainability of consumption, travel and logistics, fragile global value chains, unemployment, migration, etc., become essential to societal discourses. As a consequence, they reveal the imperfection and inability of modern political, institutional, and organizational structures to manage and solve so-called "wicked problems" that come along with them [13,16-19]. This underlines mobility as an ambivalent and reflexive phenomenon, which has brought about positive economic and social effects, such as wealth, international collaboration, and exchange. At the same time, though, there are issues, such as increased inequality, climate change, urban sprawl, and unsustainable mobile lifestyles, which are highly dependent on carbon resources. Historically, mobility has contained the idea and promise of frictionless speed as that which would lead to better and happier lives [2,20,21]. However, the realization of the vision of a "zero-friction society" [22] has in many places ended up in congestion, noise and environmental problems [23-25]. The question of how to structure the existing and future architectures, technologies, and infrastructures is in fact a form of "designing cities", of shaping their materialities, and, at the same time, their interactive spaces and social environments.

The "smart cities" discourse is frequently connected to a sort of "engineering logic" aiming for optimizing the social layout, the urban infrastructure and networks, and (at least) parts of human interactions [26,27]. Often, "smart cities" are considered as coded spaces facilitating self-learning socio-technical environments grounded in IT and artificial intelligence, where software is applied to facilitate the efficient use of resources, space, infrastructure and energy, and to provide user-friendliness and sustainability [28]. Alternatively, they are seen as assemblages of technologies aimed at increasing competitiveness, administrative efficiency, and social inclusion [26,29-33]. These ideas of the smart city have been strongly criticized for being an enforcement of the "technocentric planning paradigm" [22,34] where the planning of movements in cities focuses mainly on traffic, with "seamless mobility" as an almost unchallenged principle for an efficient organization of societies [35,36]. Against the background of the growing debate on smart cities, it becomes even more important to integrate the human scale and the social and cultural practice systematically in scientific analysis, planning, business models, and collaborative work on the future of urban living and working conditions [27].

This paper sets out to discuss the concept of smart cities with a specific focus on automation and mobility. We understand cities as a socio-material constellation of physical, technological, social, and cultural elements. We present a critique of the dominant discussion around smart cities that focuses mainly on technological innovation and in which the smart city becomes a neoliberal growth machine. Following this, we lay out the methodological and analytical concepts of discursive storylines as a constitutive element in (urban) discourses. We consider discourses on the implementation of automated mobility in urban spaces as an essential dimension of the socio-technological change in urban environments. Specifically, we focus on those storylines aiming for the risks and chances of implementing automated driving in the near or distant future. In many ways, it seems that the current storylines, to a high degree, reinforce and (re)produce the "system of automobility" [37] as the taken-for-granted form of modern mobility that will be sustained through smart and green mobility innovations and modifications. In this article, the metropolitan region of Munich is used as an example, as it is one of the incubators of the German automotive industry in the field of automated driving and vehicle development. This analytical part refers to ongoing research and presents preliminary findings. It also refers to earlier research on mobilities innovations in metropolitan regions (see e.g., references [38-40]). The analysis aims for an understanding of automated driving as a key element of smart cities beyond mere individual choices, technological innovations and economic processes. The conclusion presents an outlook for the future of automation in cities. 


\section{Smart Cities Understood as Technological Innovation and a Neoliberal Growth Machine}

The debate around "smart cities" is still very dynamic and open and it lacks clear definitions and sharp distinctions. Some of the prominent concepts in the field are currently the digital, the virtual, the networked, the connected, and even the cyber city [26,41-43]. Beginning in the early 2000s, many of these debates coincided with the increasingly powerful discursive framing of smart cities [26]. For some authors, the smart city discourse is concerned with developing and deploying new technologies in cities for a range of sectoral objectives [44-47]. Others see the smart city as an assemblage of technologies aimed at increasing competitiveness, administrative efficiency, and social inclusion [29-33]. It thereby becomes counter-intuitive to argue against the idea of smart cities because of its inherent normative character [48]; this is also the reason why little research has been conducted so far on the underlying principles and ideas of the smart city as a model [49-56], as well as critical analyses of the socio-economic, spatial, and cultural implications of new technologies on cities [26,57-59]. In other words: there is a lack of research into what, exactly, is driving the development and the rise of "smartness" in urban environments.

More recently, authors such as Hollands [48], Söderström et al. [60], and Hajer [61] started considering urban smartness also as a process in which small-scale initiatives, more or less complex forms of governance, and participation play a key role in creating the new urban digitalized fabric. Recently, here in this journal Hajer et al. [62] argued for a sustainability policy approach that lies "beyond cockpit-ism". They pointed out that sustainability strategies will fail if not being strongly rooted in urban governance and powerful "energetic" networks of stakeholders in business, cities and civil society. Sustainable development can succeed by connecting the global and territorial spaces in a multi-level concept of policy-making and planning. It is not the smart city but the "smart urbanism" that is needed to powerfully design the "desirable" instead of the "expected futures" [63]. In his 2016 book "What is the Future" [64], Urry makes a similar point saying that the future of modern societies is full of "wicked", almost unsolvable problems. Therefore, the construction of desirable futures has to happen in specific social settings which include thorough analysis of the specific historical and social conditions of the problems and their socio-material and socio-technological environments. Similarly, Freudendal-Pedersen and Kesselring [64] elaborate a transdisciplinary and cross-sectoral methodology for developing desirable mobilities futures and infuse its discourse with an understanding of all the elements that make up cities. Considering which technologies can be put into the urban space is not sufficient; it also needs a meaningful strategy based on shared perceptions of future mobilities. Otherwise, cities lose their capacities for realizing the "desirable" and they become dominated by the possible future technologies grounded in artificial intelligence. In the following, we elaborate this consideration by referring to the example of the Munich region.

From the early 2000s onwards, the smart city discourse has become hegemonic in articulating solutions to the risks and unintended externalities of increasing demographic trends that are caused by the urbanization of the 21st century and environmental concerns about climate change $[48,61]$. This is based within a regime of technological innovations and the digitalization of society [65]. In this context, smart cities promise to solve urban problems (such as environmental degradation, traffic congestion, inefficient services, etc.) to increase economic prosperity. Citizen participation will be facilitated by bringing together a range of innovative technologies, infrastructure, and data management techniques [26,48,61].

This quasi ideological background of the smart cities discourse revolves around the neoliberal notion that global competitiveness among cities will automatically make them better places to live in [49]. Cities are evaluated according to the degree of smartness that they sell [50,60], creating a new "economy of worth" [66]. In particular, policy-makers see smart cities as a set of ad-hoc devices, proposals and instruments that can be applied to respond by priority to the imperatives of economic competitiveness and global environmental change [65]. In this context, the main reason for the strength of the smart city discourse in policy arenas is its capacity to reduce complexity and provide access to immediate and efficient action in urgent urban problems. For Kitchin [27], the smart cities discourse 
is an example for a "one-size-fits-all narrative" that makes it highly ideological in its nature. As he puts it, in fact, the smart city rhetoric hides the inconsistencies, antagonisms, and conflicts behind the seemingly consensual policies of the digitalization of urban spaces, economies, and social spheres. Taking this into account, there are many good reasons for a thorough analysis of smart city policies and promotion strategies aiming to "illuminate the ways in which the concept is bound up in the shifting rhetoric and socio-spatial processes of governance and economic development" [27] (p. 132). This is also to better understand the discursive power of the smart city concept and its discursive practices, which obviously are appealing to stakeholders and make it difficult to see alternatives.

\section{Storytelling as a Means of Making Futures-Methods and Materials}

As highlighted by the above, planning for the future of mobilities has become a "messy business" full of "wicked problems" [19]. In many ways, politics and planning equals "walking on quicksand" [67], as social, political, and economic risks, uncertainties and instabilities are shaping the institutional and societal environment for policy-makers, planners, and decision-makers of all kinds. Finding consensus and generating lasting and reliable decisions has become a major problem for democracies and their institutions.

As a response to the complexities and uncertainties of contemporary policy-making, the notion of "story" has been introduced [19]. The authors of the "argumentative turn in policy analysis" understand planning as a form of storytelling and put themselves in the tradition of "communicative action planning" [68], influenced by Habermas' work on communicative action. They consider argumentation through storytelling as one of the main social activities to initiate social change or maintain existing regimes $[19,69]$. Studying storytelling can reveal how and why a specific policy object became an option. It gives access to a deep understanding of problem definitions and solution design based on shared understandings of "the" problem. It also explains how other possible options and solutions become excluded, by putting the problem under investigation into perspective and reflecting broader discourses that have shaped how cities function over the years. In the case of the smart city, storytelling could reveal overarching discourses on the national, European Union (EU), or even global level, grounded in the idea of competitiveness, the car as a status-symbol, safety, economic growth, etc., and show how these overarching discourses influence local discourses.

This paper draws upon Hajer's argumentative discourse analysis (ADA) as an inspiration for the analysis and interpretation of storytelling of automated driving in the context of smart cities. Hajer [70] (p. 66) defines discourse analysis as "the examination of argumentative structure in documents or other written and spoken statements as well as the practices through which these utterances are made". According to Hajer and Dassen (2014) [71], the formation of the smart cities discourse revolves around five key characteristics.

(1) The dominant concepts are smart grids, big data, efficiency, infrastructure, system, energy, monitoring, and information, which highlight a "managerial take" on cities with the new possibilities of ICT tools being applied to urban problems (ibid).

(2) Smart cities are typically discussed within "glue coalitions", which are new cross-over forums where business, government, and knowledge institutes meet each other, but their enthusiasm has not penetrated into academic debate. These forums function as discourse coalitions that reproduce a particular way of seeing and perceiving society. Some representative examples are the "Guggenheim lab" organized by BMW, the Crystal pavilion in London built by Siemens to showcase the future of the smart city or the Inzell Initiative, which is a cooperation between the State Capital of Munich and the BMW Group [71].

(3) The smart cities discourse is often being institutionalized through liberal practices, such as public-private partnerships. As part of this shift from public service and infrastructure to public-private partnerships, the way in which consumers pay for their urban services is likely to change and public works will be replaced by a "pay per" approach [57]. While this change might provide a fertile ground for urban entrepreneurship, it ignores how cities work sociologically 
and politically, and how particular understandings of smart cities relate to the existing system of governance [72].

(4) Within the smart city discourse innovation gets approached mainly as a technological matter. Often, its protagonists neglect the social complexity of urban environments and the contested nature of regional and local debates and decision-making. The move from problem to solution is frequently made too fast and it leaves very little time for debate. In other words, the conditions under which the future of sustainable cities has to be achieved are not discussed adequately [71].

(5) Finally, the smart city discourse lacks historical sensitivity and awareness. Case studies show that it often fails to articulate why things are the way they are. Urry (2016) [73] points out that missing knowledge and awareness of historical developments very often are the reason for failure in urban and technology policies. This attitude reproduces the technocratic planning regime of modernity, where positivist ideas, rationalism, functionalism, and the universal power of generic optimal solutions based on quantitative models were dominant [60].

In particular, we focus on the analytical concept of storylines. A storyline reflects a specific discursive understanding of a given topic, and thus it is communicated by political actors in efforts or struggles to institutionalize their understanding of a given topic in practice [70]. Decision-making is seen as constituted by and constitutive of specific discourse coalitions, which (as actors) come to be organized around a specific storyline and a set of practices communicating and (re)producing that given storyline (ibid). In other words, storylines as "narratives on social reality" "cluster knowledge, position actors and are essential in the formation of coalitions in a given domain" [74] (p. 63). Therefore, storylines allow for an analysis of the relational interaction between actors' talk and action, in order to explain how policy objectives come into place. Actors might reproduce a (dominant) storyline to retain a given set of institutions and practices, or they might construct an alternative or counter-storyline to contribute to the transformation of a policy. Thinking in terms of dominant storyline versus counter-storyline helps to highlight how storylines are produced in relation to each other, and how a counter-storyline only gains its meaning through its relation, or contrast, of a dominant storyline [75,76].

The background research that was used for this article has been conducted by the authors throughout the last two decades in Munich [40,77-81]. Some of the research has been conducted within the doctoral program "Sustainable Mobility in the Metropolitan Region of Munich: Shaping Mobility Cultures" and the postdoc program "Mobility Cultures in Megacities" [82,83]. The research is also part of the Jean Monnet Erasmus+ research network Cooperative, Connected and Automated Mobility: EU and Australasian Innovations (CCAMEU), in which the authors are responsible for the German and the Danish research hubs on Smart Cities and Sustainable Mobilities.

This paper specifically draws on ongoing doctoral research on automation in the Munich region. The empirical material presented in the analysis stems from seven expert interviews with planners, politicians, and business people, a systematic data analysis of twelve key documents from the City of Munich, the German Ministry of Transport (BMVI), and the European Commission and Parliament, and a systematic content analysis of two major websites, which contain key information and further documents on the topic.

\section{The Beginning of the Story about Automated Driving: The Case of Munich}

The region of Munich in the German south is a major place for the automotive industry. It is the home of the BMW Group, MAN, and Siemens. It builds one of the main clusters where companies, public authorities, knowledge-based industries, and start-ups develop technologies, concepts, and business models for the future of mobility. While, in the 1980s, regional techno-politics of mobility and transportation followed a single-track strategy in favour of the car, since the mid-1990s the political rationale behind transportation policies was to explore innovative potentials through the diversification of transportation modes. This has been named a "two track strategy" [38], aiming for sustainable mobility with the expansion of the public transportation system and the optimization of the road network and its IT-based infrastructures. This might also be one of the reasons why international 
industries, such as BMW, Siemens, Microsoft, Google, and others consider Munich as a laboratory for future mobility concepts [84,85].

In the 1980s, Munich was a significant place for the first road-based experiments in automated vehicles. In 1984, the computer scientist Ernst Dieter Dickmanns and his team at the University of the Federal Armed Forces in Munich (Unibw), supported by Daimler-Benz, presented a vehicle that used dynamic models for visual automated guidance (Interview VII, 2018). The Mercedes-Benz vehicle was a five-ton van that was able to carry the large computers and cameras of the time and managed to drive autonomously—only with the help of cameras, without radar and GPS $-20 \mathrm{~km}$ at $96 \mathrm{~km} / \mathrm{h}$ [86]. After its success and from the 1990s onwards, car companies, such as Daimler and BMW, decided to invest in the technology of dynamic vision [86]. The 1990s and the 2000s was a long phase of latent discussions on automated driving (see Table 1 below). On the one hand, the focus in Munich politics was on intelligent transportation systems, optimization of traffic flows, and technology-based optimizations of the public transportation system. On the other hand, the automotive sector continued to incrementally develop active assistance systems with main milestones: (1) the Electronic Stability Program (ESP), which prevents vehicle skidding and has been available since 1995, (2) semi-automatic driving introduced by Mercedes' Distronic System in 1998, and (3) mobile navigation devices available on the market since 2004 [86]. The automotive sector early on discussed automated driving actively when it came together with the general debates on automation of production systems and the use of artificial intelligence [85,87]. During this phase, automated driving was not a topic of public discussions or debates.

Around the year 2013, public policy-makers started to discuss automated driving in the context of Munich and beyond. Stakeholders started to perceive automated vehicles as a yet-to-come but realistic and increasingly concrete phenomenon. In the first place, these discussions were mainly technical, focusing on the elaboration of the automation levels (SAE) from 1 to 5 [88]. The content of discussions, when municipal planning authorities started thinking in collaboration with the industry, changed, and reached a new level of concretization in 2016 with the publication of the four-year Research Program for Automation and Connectivity in Road Transportation of the German Ministry of Transport (BMVI). The research program aims for the integration of technological and socio-political questions on automated and connected driving in urban contexts all over Germany [89]. Local and regional policy-makers became aware how the technological development went surprisingly fast: “( ... ) we are not talking on a laboratory level anymore, but about the integration into reality, into urban ground" (Interview IV, 2018). A symbolic tipping point occurred in February 2017: Dieter Reiter, the Mayor of Munich, entered the event hall of the eleventh plenary meeting of the regional platform Inzell Initiative (Inzell Initiative is a dialogue platform for mobility started by the City of Munich and BMW in the 1990s. It includes other relevant mobility stakeholders, and it represents the institutionalized collaboration between the industry and the City of Munich.) sitting in the passenger seat of an automated test vehicle. This was the first time that a bigger audience of relevant stakeholders from the industry, public administration, public transportation, as well as universities was gathered to discuss the "vision of automated driving" for the future of mobility in Munich in a more strategic and coordinated way than before (Interview I, 2018). This resulted in the submission of a joint project application by the City of Munich, the BMW Group, and the University of the Federal Armed Forces in July 2017. The application was approved in October 2018 and the collaborative research project EASYRIDE launched. The main objective of the project is for Munich to become a role model city for automated and connected urban mobility by developing different scenarios for the implementation of automated driving in the city [90]. 
Table 1. Milestones in the discourse.

\begin{tabular}{|c|c|}
\hline \multicolumn{2}{|r|}{ Milestones in the Metropolitan Discourse on Automated Driving in Munich } \\
\hline 1984 & $\begin{array}{l}\text { Ernst Dieter Dickmanns (Unibw) presents a vehicle that used dynamic models for visual } \\
\text { automated guidance }\end{array}$ \\
\hline $1990 s-2000 s$ & Long phase of latent discussions on automated driving \\
\hline 2013 & New phase of public discourse, increasingly concrete \\
\hline 2016 & Intensified collaboration between planning authority and industry partners \\
\hline 2017 & Mayor of Munich presents an automated car at a public event \\
\hline 2018 & $\begin{array}{l}\text { Launch of the collaborative research project EASYRIDE funded by the German Ministry of } \\
\text { Transport }\end{array}$ \\
\hline
\end{tabular}

In the following, based on this short historical outline, we will elaborate on the Munich discourse through storytelling about automated driving in the smart city of the future. Discourse is defined here as "a specific ensemble of ideas, concepts, and categories that are produced, reproduced and transformed in a particular set of practices" [74] (p. 44). This social-constructivist and pragmatist understanding of discourse puts talk and decision, communication, and practice in a close and indivisible relationship. Referring politically and materially to automated driving is, at the same time, part of defining the problems that are connected to it and narrowing down possible solutions, instruments, and measures. Currently, this is one of the results of our research; the local discourse is still in an early, dynamic, and fluid state. Different stakeholders are emphasizing different aspects and favour different ways to approach the implementation of technology and infrastructure. Neverthelss, even in this early phase we can see significant structures and developments.

\section{Storylines about Automated Driving in the Future City of Munich}

We present four dominant storylines as structuring elements of the local and regional discourse. This gives an impression of how global, European and national discourses are translated and contextualized into local/regional scales. Looking at the main storylines and analysing how these become presented as a specific "plot", highlighting specific aspects shows quasi automated driving in the making and how a future mobility mode in the city evolves and manifests locally. We do not claim that this is representative for Germany or even beyond. The case study illuminates different discursive strategies of how to politicize, promote, hinder, or even sabotage the implementation and institutionalization of automated driving in an urban context.

The four storylines focus mainly on efficiency, innovation, competitiveness, and technology. All four are interconnected, but, as in earlier research in Munich [38,76,91], we can identify a process of preliminary coalition building. We expect that, in the near future-with all scientific caveats-these discourse coalitions will be powerful promoters and/or opponents of automated driving in the context of smart cities in Munich. As we mentioned before in the introductory part of the article, these discursive, communicative, and interactive practices are part of defining the problem and narrowing down how it can/will be solved (or not) through automated mobility. The preliminary findings presented here do not show the full complexity of the analysis but summarize the main results and aspects found in the dataset.

\subsection{Efficiency—The "Word for Everything"}

The storyline of automated driving as a means of efficiency has been articulated by all stakeholders at all levels of governance $[90,92,93]$. On the urban scale in Munich, stakeholders express that "efficiency is basically the word for everything" (Interview II, 2018). The data analysis shows that the buzzword "efficiency" has been contextualized quite differently and it comprises at least three different connotations relating to flow, space, and energy.

The "dream of traffic flow" as one of the "one-best-way strategies" [94] often applied by traffic engineers to reduce the complexities of multi-dimensional and multi-level transportation policies 
shows up in the empirical material. At least since 2013, BMW, for instance, has been in discussions with the City of Munich to change their analog traffic management tools to real-time tools. This could include automated cars, connected vehicles, and other new technology. In line with the other German car producers, BMW claims this to be the only way to efficiently coordinate and optimize mixed traffic flows online. This discussion led to a joint initiative between the local industry, research and the City of Munich for the development of a simulation tool for automated driving in real-time conditions, which is part of the federally-funded project EASYRIDE (Interview VI, 2018). Many traffic planners from the City of Munich consider this new simulation tool a milestone towards a regular speed for connected vehicles (Interview IV, 2018). This reflects the deeply embedded mentality of seamless mobility and frictionless speed as a sign of prosperity in cities $[2,20,35]$. Automated driving is also perceived to be a significant traffic calming method, because automated cars would not break traffic rules and regulations: "( . . ) this would be a process to civilize traffic" (Interview I, 2018). This argument resonates with the persistent mentality that technology can replace human messiness, eliminate human error [95] and that highway engineers can "cure" all ills [86].

The efficient use of space plays a major role in the data. Munich has often been referred to as the "city of density" and it is expecting massive demographic growth in the future. Against this background, "space efficiency" induced through automated vehicles sounds appealing to many politicians and

is something that all parties supported, because it was declared as good and helpful for the city (...) [T] he industry told us that we need fewer cars, more space (...). So, for politicians that sounds like a good thing, as we need to reduce congestion. (Interview I, 2018)

In line with Miciukiewicz and Vigar [34] (p. 1954), automated driving can be understood as a "carrier of political capital" for the provision of efficient transportation networks. Shared (automated) mobility seems to be a key opportunity for a political strategy where the lack of available space for more cars and motorways in Munich meets the potential of automated driving for a reduced need of parking space and car ownership. Some of our interviewees see this as a new opportunity for a more efficient allocation of public space (Interview IV, 2018).

Lastly, energy efficiency through block-chain and green grid technologies shows up as an important element in the data. Interviewees point out the relevance of the combination of automated, connected, and electrified technologies for sustainable energy provision. Local industry needs to achieve the emission goals imposed by the EU, while the City needs to provide clean air and sustainable energy recourses for the city mainly relying on Munich City Utilities (Interview IV, 2018). Munich City Utilities depend heavily on fossil fuels provided by Russia and Norway. It wants to achieve energy independency by using renewable energy sources [81], as a strategy to deal with the uncertainties of oil crises and resource depletion that characterize mobile risk society $[2,15,20]$. A concrete manifestation of the energy efficiency discussion is the inclusion of the term "autonomous driving" in the revised version of the Integrated Action Program for Electric Mobility in Munich (IHFEM) in 2018, where it is mentioned that automated driving needs to be combined with e-buses, and automated e-mobility to be gradually integrated into public transportation through pilot tests (IHFEM 2018). In the same vein and connected to the space efficiency aspect, the term "automated driving" has been included in the City-to-Share project since 2016. It is a collaborative project of Munich based governance platform Inzell and it aims for a more sustainable use of public space. It also brings together electric mobility, connected mobility, car sharing and automated driving. By reducing car ownership through automated sharing, the City could achieve both "space efficiency and energy efficiency" (Interview IV, 2018). One of the key partners of the City-to-Share project is the BMW Group, which has recently summarized its vision for the future of mobility in the acronym ACES (automated, connected, electric, shared): "ACES allows us to provide the city with a much higher quality of life, because we increase the efficiency of road utilization of public space ( ... ) [I]t's a fantastic world" (Interview III, 2018).

City-to-Share is nothing less than an attempt to operationalize the ACES concept in a specific urban context. However, the belief that ACES will move automatically from problem to solution 
broadly ignores the complexity of local governance debates [71]. By elaborating this based on the other three storylines, we introduce the complexity and also the inconsistencies of urban mobility discourses. We show that, by far, there is no overarching consensus or shared problem definition available at the moment which could make implementation simpler. Instead, there are still significant "contradictory certainties" [96] that show that it is hard to imagine what a consensual strategy will look like in the future. This could also explain why there has not been further elaboration in the project on how automated driving could be implemented in mixed traffic in terms of regulation and infrastructure.

Overall, the efficiency storyline with its different dimensions (flow, space, and energy) has, at face value, a unifying character where a possible consensus might lie. However, whether it can unfold, this potential to build new strong and influential "discourse coalitions" is still an open question [75]. Until now, it primarily reflects the power of the techno-centric paradigm where technology is the panacea for all problems that empowers cities to function in frictionless speed, perpetuated "green" traffic, and seamless mobility. Discursively, this reproduces the "system of auto-mobility" [37] that has been guiding local and national decision-making on mobility for decades. It has been seen as a guarantee for a high degree of individuality and pluralization that is now continued and accelerated by digitalization processes external to the initial system [36]. This will be further elaborated through the storyline of innovation.

\subsection{Disruptive Innovation}

Automated driving is often seen as disruptive innovation that will change the mobility system and even reinvent mobility to a certain degree [97]. In the following, we shed light on the two innovation aspects-evolutionary process and technological development from scratch - that are currently strongly articulated by the automotive and the ICT industry.

The first aspect refers to innovation as an evolutionary process. This is illustrated by the fact that the local automotive industry has been working on an allegedly "linear" pathway from Adaptive Cruise Control to level 2, level 3, level 4 automation (SAE levels):

We have Adaptive Cruise Control in the market since the 2000s and we started to have Electric Steering in the 2010s. The key switch that was taken was that the steering systems are not any longer hydraulic, but electric. So, only with electric steering you can make automated steering, as with electric steering the car can steer itself. Then, safety functions and Lane Keeping Systems came to the market in the 2010s, and in 2013 we started with the first Traffic Jam Assistant; that was level 2. In 2015, we started with Steering Assistance. Then, we started developing more technology inside the car, including radar sensors, cameras, and the next step is level 3 in 2021 as an option in any car and the laser scanner will come on top of it. The next i-model, the next electric car, will include level 3 driving on motorways and also in cities and then we will have level 4 automated driving with the first pilot fleets in cities. (Interview VI, 2018)

This implies a view of technological innovation as a self-adaptive mechanism, in terms of continuous improvements in safety, fuel economy, comfort, ease of use, performance, and reduced pollution. According to the local automotive industry:

These technological developments are key enablers of automated driving. So, these new technologies make it possible to do new things and that's why the whole development goes on; it's not because somebody thinks we should do this now, but because technology enables it. (Interview VI, 2018)

This reflects the perception of automated driving as an inevitable and irreversible transformation that will take place no matter what, because technology itself drives the innovation process. However, this neglects the socio-technical aspect of innovation as well as the human agency in the development and combination of diverse technologies. As Latour [98] states, innovation is an assemblage of different 
technologies and human actors, and it "always comes from a blending or redistribution of properties that previously had been dispersed" [99] (p. 36). Therefore, recent attempts to achieve higher levels of automation do not necessarily imply inventing new basic technologies. In the case of automated driving, this translates into the strategic selection, integration, and combination of automation and ICT technologies invented and developed in the 20th century (i.e., computers, sensors, the Internet). Based on this, it comes as no surprise that ACES, just like the Daimler concept CASE (connected, automated, shared, electric), has become a comprehensive package of innovation for the future of mobility for the original equipment manufacturers in the market. It is the automotive industry as an actor that deploys a blending of technological innovations (i.e., automated functions, electric drive, and connectivity technologies), which enable each other's' functionality, supported by business and product innovations, namely car-sharing services and on-demand mobility.

At the same time, local authorities do not mention anything about institutional or social innovations. The tests being conducted around and in Munich are not run in collaboration with local authorities. The test routes "belong to industrial territory" (Interview VI, 2018), which indicates that the local authorities are not being part of the innovation storyline. Instead, there is an expectation that the City will set up a framework to "help innovation to be implemented, because there is an interesting ground for businesses to step into that market" (Interview II, 2018).

The second aspect of innovation is about technological development from scratch. Companies like Google-Waymo, Apple, and Uber put pressure on the market through developing automated cars on level 4-5 from scratch and by incorporating the latest high-tech software solutions. These "new players" in the market act from outside the generic field and invest significantly more resources in their prototypes. Their innovation and development pace is also much faster (Interview VI, 2018). Furthermore, by introducing new business models (e.g., Google and Uber fleets), they are putting pressure on the car industry to diversify their business model introducing on-demand and car-sharing fleets, like ReachNow and DriveNow (BMW) and Moovel and Car2Go (Daimler) [100].

As a defensive response to rapid ICT industry developments, car producers claim that they rely on the expertise that they have in terms of driving physics and safety in real life conditions. They see it as being more important than the rapid development and testing of high-tech prototypes in ideal conditions (good weather, no pedestrians, etc.) (Interview III, 2018). The general perception of the German automotive industry, expressed in round table discussions at national and European levels, is that in Germany "there won't be safety issues like in the US" (Interview VI, 2018). However, this rapid technological innovation in car technology from external actors implies crisis for the automotive industry, because a multitude of diverse actors (from ICT companies to start-ups) are threatening its hitherto predominant position in the market. This highlights the importance of artificial intelligence and digitalization, which might be key drivers in shaping the future of mobility in the context of smart cities $[36,87,101]$.

In a nutshell, there are two different processes of innovation articulated; an evolutionary process within the automotive industry and an external rapid process by new players. In both cases, the discourse of automated driving is (re)fuelled by concrete technological and business practices and materialities through the storyline of innovation. On the one hand, automotive industry actors are subject to fundamental path dependencies that contribute to an optimization of the existing system, rather than radical change. On the other hand, the new players seem more disruptive in their production processes as well as in the promises that they make for the rapid diffusion of automated driving. In either case, innovation is approached primarily as a technological and business matter, with the local public sector not being part of the innovation discussion. Nevertheless, as we will show through the storyline of competition, the role of the public sector lies in between the industries. 


\subsection{A Manifestation of Competitiveness}

The storyline of automated driving as a means of competitiveness is being articulated by the automotive industry, the Public Transportation Company of Munich (MVG), and some parties of the City Council (mainly the Social Democrats). This storyline further elaborates on the synergies within the automotive industry, the outside competition, and competitiveness between cities, and reflects embedded ideas of glue coalitions [71], public-private partnerships [71], and neoliberal urbanism [102]. In the following, we elaborate on the following two aspects of competitiveness: old and new players, and providing the sandbox.

The first aspect of this storyline is about competitiveness between old and new players. The German automotive industry is under pressure from massive international competition. For this reason, "Germany as the country of the automobile is compelled to take action towards the implementation of autonomous driving, so that it won't stay behind global developments" (Interview I, 2018).

This is basically not about mobility, but an economic argument ensuring that Germany will "be the best in class just to export a product" (Interview V, 2018). This is a game of dominance between car manufacturers and ICT companies (Interview I, 2018). In the same vein, the logic of Google is not whether automated driving is necessary or not, but that "it will happen anyways, because it's possible", and that is why "we have to do it faster than the Chinese" (Interview V, 2018). In other words, the local automotive industry is part of a technology-oriented international competition coming mainly from the Silicon Valley and China [103] but not only from there:

The biggest competition is very close and very far. It's Stuttgart and California. Waymo, Apple, Uber are the biggest competitors ( . . ) worldwide and if we look more into the area of premium mobility it is Daimler, very obviously. ( . . . ) BMW and Daimler are in front of the development worldwide. (Interview VI, 2018)

This shows clearly the dual competition that the automotive industry in Munich is experiencing from both inside and outside the national market. It also indicates the synergies that the German automotive companies develop to secure their position in a global mobility market [101]. This might be a reason why many car producers seem to have almost identical visions for the future of (urban) mobility (see ACES-CASE).

Another manifestation of competitiveness between old and new players is in the field of public transport and between the public transport company (MVG) and BMW. MVG is interested in automated busses and shuttles, which could solve the first and last-mile problems and increase accessibility. At the same time, MVG wants to maintain their monopoly as mobility providers in the City, as they fear "new players will enter the market" (Interview V, 2018; Interview I, 2018). A practice that illustrates MVG's attempts to secure their hitherto unchallenged position is their attempts to lobby for the inclusion of all on-demand services (e.g., car-sharing, ride-sharing, bike-sharing, etc.) in German public transportation law (Interview III, 2018).

Another aspect of this storyline is about providing the so-called "sandbox". The "sandbox" is about the City providing the regulatory framework and fertile ground for the industry to implement automated driving in the city of Munich. Transportation politics have been strongly shaped by Munich mayors since the early 1990s. In 2017, the current Mayor began promoting visions of competitiveness within the City Council by stating that "Munich shall be one of the most progressive cities in automated driving in the world" (Interview I, 2018). The City Council decided to support the local industry, as a vital economic pillar of the city. This perception is clearly summarized in the statement of a local public transportation expert: "[I]f BMW is good, the City of Munich is good" (Interview IV, 2018)

This way the interests of the City are aligned with the well-being of the industry without the City positioning themselves as a separate democratic entity that represents local citizens. This reflects a "roll-with-it" neoliberalization of governance, where the normalization of neoliberal practices and the de-politicization of decision-making becomes the basis of action [3]. BMW describes this collaboration with the City as a win-win situation. On the one hand, this collaboration allows BMW to legitimize 
their dual business strategy as a traditional car manufacturer and as a mobility provider of on-demand services. BMW expects the City to set the framework for land use allocation for mobility modes, parking space, traffic flow, road pricing, and emissions without interfering with the technological developments or public acceptance of the new technology:

Our message to the City is “don't talk about technologies, don't talk about customer behavior and mobility choices, do what you need to do and don't care about anything else. So, define quality objectives, attach a price to that, that's it. And then you define a sandbox and then let the kids play in the sandbox" ( . . . ) then the City can lean back and say "OK, whatever technology comes in, so be it ( ... ) we have defined our sandbox" (...) We don't want a specific regulation for automated driving, we just want the regulation for the current mobility problems to be solved. (Interview III, 2018)

On the other hand, this "sandbox" is supposed to be beneficial for the City as well, as congestion and emission problems need to be solved anyway. Moreover, if they "let the kids play in the sandbox", Munich will secure a competitive advantage of safe automated mobility as a city, which helps it compete with other cities nationally and globally (Interview III, 2018). The discussion about the provision of the "sandbox" started materializing through the cooperative project of Inzell Initiative's EASYRIDE, aiming for a comprehensive plan that will set the framework for the implementation of automated driving in Munich (Interview III, 2018, Interview IV, 2018). However, as the storyline of "another Tamagotchi" shows below, the City of Munich planners are still quite uncertain about this laissez-faire approach that is articulated by the industry and they hesitate to regulate.

\section{4. "Another Tamagotchi"}

The storyline of automated driving as "another Tamagotchi" is articulated by some politicians and planners, who are hesitating to regulate, who are reactive instead of proactive, and are not fully convinced by the technology. They view it as a sandbox that is good to have, but they do not see it as an actual part of the solution of urban mobility problems and prefer to wait for the industry to come up with better technology. This is expressed in this storyline as "exploring the trend" and "dealing with responsibility".

For planners, automated driving emerged as a trend that needed to be explored through discussions in round tables, conferences and public discussions. This made them gradually approach the topic actively, but it still remains a trend they are unsure they should follow:

As a paradigm, we could say that the City wants to use the trendy scenario in terms of how we can create a more sustainable urban transport. There is a high potential that automated driving is part of the future of mobility, but of course we don't know ( . . ) It could be a bubble blast and that nobody is talking about automated driving in 10 years $(\ldots)$ like look at Tamagotchi $(\ldots)$ we all know trends like that $(\ldots)$ they can just $(\ldots)$ explode and they are gone then. (Interview IV, 2018)

As an administrative body with limited resources that wants to approach a new high-tech futuristic topic, such as automated driving, they see it as the "Tamagotchi 2.0". This means that they need to explore whether the trend fits into their existing framework and gain more knowledge about how autonomous driving can be included in the City's overall mobility strategy (Interview IV, 2018). However, the fact that they want to follow a "paradigm of trends" but simultaneously hesitate to take action appears to be contradictory, as if the paradigm were external to their internal administrative structures and local social realities and they were trying to figure out whether they can bridge the gap. This tendency to follow trends resonates once more with the "roll-with-it" neoliberal mode of governance [3] that was mentioned before, but its limited potential for adequately conceptualizing mobility problems is also evident here. An indicator that automated driving is not yet a vital part of the City's vision for mobility is the recent resolution of the Planning Department for the new Mobility 
Plan for Munich from July 2018. The only strategic orientation related to automated driving is as a supplement to public transportation, with no further elaborations [90].

This illuminates the second aspect of the storyline related to responsibility. The administration believes that it is still too early to discuss on a policy level and on a conceptual strategic level: "the City has no final point of view on that topic, because it is too early and too young ( ... it's immature" (Interview IV, 2018). Despite how the industry presents automated driving through ACES as an efficient and fast solution, the planners don't automatically accept automated driving as a "silver bullet", but they think of several risks it might entail, such as deteriorating traffic congestion, increasing travel and urban sprawl as well as taking people away from public transportation. They "don't want to be an industrial playground" and they need to know whether there is potential before they take any risks (Interview IV, 2018). The automotive industry interprets this as a conservative German mentality on the part of the City, claiming that the public sector traditionally is afraid of anything new (Interview III, 2018). As a result, nobody takes responsibility for the issue at the moment and then both sides are waiting for each other. The following short dialogue has been put together from data collected from two different interviewees representing the Administration of the City of Munich and BMW, who, during the respective interviews, recalled the discussion they had with each other at a round table meeting they both attended:

- Administration: "We are not prepared, we don't have the necessary systems IT-wise ( . . ) you have to tell us, basically, how fast this technical development will go, when we need to be ready" (Interview IV, 2018).

- $\quad$ BMW: "Please, you should tell us what you want (... ) OK, we would like to do something, but what is your framework?" (Interview II, 2018).

- Administration: “OK, but it's not our job, it's not our responsibility, because we are just responsible for roads and traffic management and traffic signals ( ... ) but Munich should do something about it. We would like to have Munich as a showcase ( . . ) we want something to happen, but we don't want to have the responsibility for it" (Interview IV, 2018).

At the same time, politicians are a bit "lost in translation" between the Administration and the automotive industry:

Politicians are like "Hans and Franz" on the street, so they have no clue (...) for them technology is like the jewellery ( . . ) they take the technology and say, "hey, I am so progressive", they push things forward, but they have no clue what the implications are and what they really need to do. So, for them, it's just like ribbon-cutting events and publicity. (Interview III, 2018)

Even if politicians make statements in the media showing excitement about autonomous driving, it does not necessarily mean that they have the political will to make the radical decisions that automated driving requires. Overall, the inherent complexity of the topic makes it difficult for the actors to comprehend in full the various interests around the different automated driving scenarios. This can lead to no decisions being made, isolated solutions, and grey areas, for which perhaps no one takes responsibility (Interview I, 2018). This reflects the inability of contemporary political, institutional, and organizational structures to manage and deal with the risks and uncertainties that come along with complex and "wicked problems", such as the implementation of automated driving [16-18].

\section{Discussion of Storylines: From Efficiency to "Another Tamagotchi"}

The storyline of efficiency has been introduced as an "umbrella term" attempting to provide consensus in the local discourse on automated driving in Munich. It is perhaps the oldest discursive construction in the techno-politics of mobility in Munich, perpetuated through the discourse of automated driving. All of its dimensions (traffic flow, space, and energy efficiency) have managerial connotations. In many ways they function as a sort of smokescreen for some of the deeply political 
debates around private cars and alternative modes of transportation. In the 1990s, local politics in Munich was formed by a philosophy focussing on those issues where consensus was achievable instead of getting stuck in highly conflictual topics. Based on the material, it seems plausible that the dominance of the efficiency paradigm has roots in this political strategy and it works as a discursive strategy to cover contradictions and avoid unsolvable conflicts. In line with this, "efficiency" is being used as an abstract term to indicate a possible future that can successfully solve mobility and transportation problems.

The discursive potency of efficiency, though, seems to be fading due to its inability to contextualize the deeply socio-political transformations happening within the system of auto-mobility. This is further elaborated through the storyline of innovation, which is divided into two processes of innovation. Firstly, the evolutionary innovation that refers to automation as a "natural" evolution of technology, and, as such, it strengthens the path dependency of the automobile. This "natural" evolution is articulated by the automotive industry, and it obscures the politics and the competing deliberation behind the development of automation technologies over the years. Secondly, there is the innovation from scratch that refers to the accelerative and rapid process of digitalization that is represented by the ICT industry, which challenges the automotive industry. Both processes are oriented towards technology and business and overlook social and public institutional innovations.

The storyline of competitiveness further elaborates on the transformative crisis that lies in the automotive industry caused by global competition from new players in the ICT industry, primarily from the United States (US) and China. As a result, the automotive industry is searching to develop alliances with other automotive companies, while also competing with public transportation companies, in order to enter the field of mobility service provision and secure a leading position in this market. Furthermore, it clearly shows the industry expectation that the City needs to accept a neoliberal governmentality, where their role is to provide a fitting "sandbox" where the regulatory framework and fertile ground for the industry can be created. This does not provide space for desirable futures, but it focuses on futures likely to happen influenced by global dynamics that are mostly disconnected from local social realities. This missing social connectivity is expressed through the storyline of "another Tamagotchi". This storyline is mainly articulated by planners and it illustrates an insecurity about the potentials of automated driving and if automated driving will improve urban mobility. Also, this has an influence on the political system where the political will for implementation seems to be absent.

Overall, the first three storylines (efficiency, innovation, and competitiveness) do not appear to be connected directly to concrete practices but are more a matter of coalition-building in the making of an early state techno-political discourse around automated driving. Until now, when it comes to concrete practices, the industry waits for the City, with the only exception being the two research projects mentioned (City-to-Share and EASYRIDE). These are pilot projects and far from actual implementation, which shows that the automotive industry is not very decisive in their implementation strategy so far. The "another Tamagotchi" storyline shows that, although automated driving is discussed as a game changer for the future of mobility, it is not yet an essential part or element of official policy concepts of the City or even an urban strategy.

\section{Insights and Concluding Remarks}

The case of policy-making of automated driving in Munich exemplifies ways in which private and public actors (re)produce the principles of the system of automobility. This happens along with technocentric and neoliberal modes of governance for mobility in the context of smart cities. However, also an emerging tendency of the public sector can be detected to slow down the rapid implementation of high-tech solutions and reflect on their implications for the future city. Since research on the policy dynamics of autonomous driving in urban contexts is underrepresented, it is difficult at the moment to cluster the case of Munich with other examples worldwide. However, a preliminary observation is that American cities, which have different topography and modes of governance, reacted more openly and faster to the technological developments coming from the Silicon Valley, at the beginning. 
Nevertheless, after the recent accidents of automated vehicles in the US they started rethinking their implications more carefully.

In line with this, despite all advertisements and strategic statements from industry representatives worldwide, the analysis shows that both the industry and the municipality in the region of Munich remain (willingly or unwillingly) "in a state of limbo" when it comes to the implementing of automated vehicles in the city. This is different from attempts to manage automation on highways, where first applications are expected in 2021 or 2022, but still stakeholders are currently in a state of waiting for the "others'" reactions and decisions and avoiding taking over responsibility. This reflects the current institutional inertia in dealing with the risks and uncertainties of automated driving. It highlights how "perceived" risks have become contextualized in local socio-technical discourses on automated driving and as a 'material' example for the status of the smart city discourse in a concrete urban environment. Further on, it reveals the inability of modern political, institutional, and organizational structures to manage and solve so-called "wicked problems" that come along with urban risks [13,16-19].

In the case of automated driving, the complexity is much higher when it comes to the actual implementation in historically grown built environments with high levels of uncontrolled, sometimes spontaneous and socially interactive mobilities [104]. Vehicles need to navigate the complex and heterogeneous worlds of city streets and interact with people, local mobility cultures, other vehicles, traffic of all kinds, infrastructures and landscapes. The history of the modern planning paradigm has proven that building cities in a default way can create urban environments that are nasty to live in and costly to get around. This resonates with the fact that many planners hesitate to regulate for automated driving, as urban politics is an arena for making difficult and contested choices. The planners in our case are rather uncertain about the potential of the neoliberal mode of governance that is promoted by the private sector. The City, in this case, is expected to adopt the role of the mediator between different industries and public transport, rationalized through their duty of providing citizens with opportunities for transportation. They handle this by attempting to overcome the dichotomy between the system of automobility and public transport and instead operate within a new "system of diverse mobilities". In consequence, they need to deal with several competing global and local providers. This demands more complex modes of governance and includes more economic and social risks. It underlines how cities have changed their pulse, their pace and reach and have become an interconnected element of the global "network society" [3,4].

The analytical results of the first three storylines-efficiency, innovation, and competitiveness-are to a great extent in line with previous research on the urban politics of smart cities. Allmendinger and Haughton [105] describe the lack of adequate debate in technocratic policy-making processes as "the crisis of consensus". This highlights a significant deficit in democratic decision-making. Miciukiewicz and Vigar [34] argue that tech-led solutions are regarded by policy-makers as "carriers of political capital" and "magic bullets" for the provision of efficient transportation networks and for meeting the carbon reduction goals of mainstream sustainability agendas. As a consequence, they argue, this leads to the de-politicization of urban transportation policy-making. In line with this, Hollands [49] interprets smart cities as a "contemporary clothing of urban entrepreneurialism", which "plays down some of the negative effects the development of new technologies is having on cities". According to Söderström et al. [60], this frames smart cities into a discursive formation where urban affairs become apolitical and technological solutions can be sold to any political regime. In other words, the smart city symbolizes a new kind of a technology-led "urban utopia" [55]. This also leads to the presumption that sustainability can be reached through technological innovation. The extensive use of big data and new software applications seem a sufficient answer on urban and mobility problems in particular to many stakeholders. However, in fact, this neglects systematically highly plausible critical interpretations within political and scientific debates [60]. This reveals a systematic lack of alternatives to the neoliberal city results in "the technology fallacy" $[72,106]$ with massive consequences for urban lives, the urban condition, and everyday mobility cultures. This stands in the way of the City of Munich developing desirable futures of urban mobilities. On the other side, facing this as a fundamental problem of urban 
politics could provide the ground for a fruitful multidimensional mobility discourse amongst the City, industry and civil society, where technology becomes one element amongst others, but not the ultima ratio. Putting automated driving in perspective and developing smart solutions improving urban lives have the potential to support the sustainable development of the city. In other words, automated driving needs to be more than a new business case and model for the restrengthening of the system of automobility as the one-best-way solution for urging urban problems.

Overall, the potential for a radical transformation of mobility and cities through automated driving has been intensively promoted in media, statements from industry representatives, and round table talks worldwide [107]. However, taking into account thatthere has not been any actual implementation of automated driving in urban environments [86,108], we deduce from there that the discourses surrounding digital and automative technologies are industry-driven and aim at the development of generic smart cities. However, the complexity and the local particularities, needs and uniqueness of cities might be at odds with such a global monoculture. This is in line with Hajer's argument about the need for smart urbanism rather than smart cities and it moves beyond monocultures and integrate all that a city is and thus create:

"a powerful integrative and action-oriented body of thought on cities that emphasizes their particular histories, the social composition of cities, analyses the resources it takes to run a city, provides insights into the intricate ways in which design, politics and business interrelate and helps to think of the institutional formats and practices that can help deliver on the transition needed". [71] (p. 51)

The fourth storyline, deciphered in the analytical part of the article, has been named "another Tamagotchi". It is clearly in line with Hajer's argument and it opens up for opportunities towards a new understanding of how cities should function through the questioning of techno-centrism. The following quote from a local planner expressess this right to the point:

Predominantly we must look into the urban agenda: urban public space, clean air for everyone and availability of mobility at an affordable price. ( . . . ) So, the overall political and city goals it is, and we need to look into all the solutions that are offered by the industry: do they really serve those goals or are people just running behind a new fashion or a new trend, a new possibility? Maybe it's contradicting the real goals, because the real goal is not to have automatic cars, but to have a prosperous city, where everybody is employed in the best situation and where people like to live, where it's (...) safe to live and it's a great place to be, but keeping in mind that technology is just to serve that and not to dictate what the future of the city should be'. (Interview V, 2018)

To conclude, we believe that our case study of Munich provides significant insights of how important it is to trace the discursive deliberation of automation technologies 'in the making' for shaping the future of cities. A deeper understanding of how smart urbanism can be achieved calls for collective deliberation and discussions that allow for constructive conflict and dispute and committed debate. At the same time, desires, needs and visions need space for articulation before the lines of action are being defined. This way decision-makers can avoid reproducing the same path-dependencies again and again that pre-define solutions and conceal transparent deliberation regarding the kind of society citizens want to live in and the meaning they assign to the mobilities of everyday lives. Hajer and Pelzer (2018) [63] point out how discursive deliberation can create "ontological expansion", which is the transformative capacity of decision-makers and citizens to create things that do not yet exist. This is based on the idea that people are not persuaded by facts, but are enticed by perspective. Through articulation, fact and fiction can blur and new futures emerge. Changing practice is thus seen to always include the change of perceptions and problem definitions. Against this background, a policy recommendation proposed by Freudendal-Pedersen and Kesselring [64] is future workshops with policy-makers, citizens, and artists, which can serve as safe 'imaginary spaces', where participants will 
be able to develop ontological expansion through reflecting on and talking about how the relations of future mobilities and the city can be repositioned, move into new directions, and be utilized to generate new and seriously smarter policies. This could be a starting point of transforming the car-dependent city and the "system of auto-mobility" [37], including its predominant planning paradigm.

\section{Interviews}

Interview I (2018): Interview with Green Party politician

Interview II (2018): Interview with expert Mobility Services BMW

Interview III (2018): Interview with expert Urban Mobility BMW

Interview IV (2018) Interview with planner Department of Public Order

Interview V (2018): Interview with expert Public Transport Company

Interview VI (2018): Interview with expert Autonomous Driving Strategy BMW

Interview VII (2018): Interview with expert dynamic computer vision and automation

Author Contributions: S.K. and M.F.-P. conceived and conceptualized the topic of the paper. E.S. conducted the interviews this paper is based upon, analysed the data, and constructed the storylines. The background knowledge and literature is provided and shaped by all three authors jointly. The paper was written, reviewed and edited by all three authors.

Funding: This article was developed with the support of a Jean Monnet Network Grant, 'Cooperative, Connected and Automated Mobility: EU and Australian Innovations', co-funded by the Erasmus+ Programme of the European Union (599662-EPP-1-2018-1-AU-EPPJMO-NETWORK) and the 'Sustainable Mobility in Metropolitan Regions' joint PhD program by Technical University Munich (TUM) and Nürtingen-Geislingen University (HfWU), funded by Hans Böckler Foundation, Germany (PK 032).

Conflicts of Interest: The authors declare no conflict of interest.

\section{References}

1. Urry, J. Sociology beyond Societies: Mobilities for the Twenty-First Century; Routledge: London, UK; New York, NY, USA, 2000.

2. Urry, J. Mobilities; Polity Press: Cambridge, UK, 2007.

3. Tickell, A.; Peck, J. Neoliberalizing Space. Antipode 2002, 34, 380-404. [CrossRef]

4. Castells, M. The Rise of the Network Society: The Information Age: Economy, Society, and Culture Volume I; Wiley-Blackwell: New York, NY, USA, 1996.

5. Banister, D. The Sustainable Mobility Paradigm. Transp. Policy 2008, 15, 73-80. [CrossRef]

6. Faulconbridge, J.; Hui, A. Traces of a Mobile Field: Ten Years of Mobilities Research. Mobilities 2016. [CrossRef]

7. Sheller, M.; Urry, J. Mobilizing the New Mobilities Paradigm. Appl. Mobil. 2016, 1, 10-25. [CrossRef]

8. Freudendal-Pedersen, M.; Hannam, K.; Kesselring, S. Applied Mobilities, Transitions and Opportunities. Appl. Mobil. 2016, 1, 1-9. [CrossRef]

9. Sheller, M.; Urry, J. The New Mobilities Paradigm. Environ. Plan. A 2006, 38, 207-226. [CrossRef]

10. Canzler, W.; Kaufmann, V.; Kesselring, S. Tracing Mobilities_Towards a Cosmopolitan Perspective; Canzler, W., Kaufmann, V., Kesselring, S., Eds.; Ashgate: Aldershot, UK, 2008.

11. Cresswell, T. On the Move: Mobility in the Modern Western World; Routledge: London, UK, 2006.

12. Urry, J. Climate Change and Society; Polity: Cambridge, UK, 2011.

13. Beck, U. Risk Society: Towards a New Modernity; SAGE Publications Ltd.: London, UK, 1992.

14. Beck, U. Mobility and the Cosmopolitan Perspective. In Exploring Networked Urban Mobilities: Theories, Concepts, Ideas; Freudendal-Pedersen, M., Kesselring, S., Eds.; Routledge: New York, NY, USA, 2018; pp. 140-152.

15. Kesselring, S. TheMobile Risk Society. In Tracing Mobilities; Kesselring, S., Kaufmann, V., Weert, C., Eds.; Ashgate: Aldershot, UK, 2008; pp. 77-104.

16. Beck, U.; Bonss, W.; Lau, C. The Theory of Reflexive Modernization: Problematic, Hypotheses and Research Programme. Theory Cult. Soc. 2003, 20, 1-33. [CrossRef]

17. Beck, U.; Hajer, M.; Kesselring, S. Der Unscharfe Ort Der Politik: Empirische Fallstudien Zur Theorie Der Reflexiven Modernisierung; Leske + Budrich: Opladen, Germnay, 1999. 
18. Urry, J. Global Complexity; Polity: Cambridge, UK, 2003.

19. Fischer, F.; Forester, J. The Argumentative Turn in Policy Analysis and Planning; Fischer, F., Forester, J., Eds.; Duke University Press Books: Durham, UK, 1993.

20. Jensen, O.B.; Freudendal-Pedersen, M. Utopias of Mobilities. In Utopia: Social Theory and the Future; Ashgate: Burlington, VT, USA, 2012.

21. Rosa, H.; Scheuerman, W.E. High-Speed Society: Social Acceleration, Power and Modernity; Pennsylvania State University Press: Pennsylvania, PA, USA, 2009.

22. Hajer, M. Zero-Friction Society. Available online: https://www.rudi.net/books/11454 (accessed on 29 May 2014).

23. Banister, D. Cities, Mobility and Climate Change. J. Transp. Geogr. 2011, 19, 1538-1546. [CrossRef]

24. Urry, J. Societies Beyond Oil: Oil Dregs and Social Futures; Zed Books Ltd.: London, UK, 2013.

25. World Business Council for Sustainable Development. Mobility 2030: Meeting the Challenges to Sustainability. The Sustainable Mobility Project; World Business Council for Sustainable Development: Geneva, Switzerland, 2004.

26. Willis, K.S.; Aurigi, A. Digital and Smart Cities; Routledge: Oxon, NY, USA, 2018.

27. Kitchin, R. Making Sense of Smart Cities: Addressing Present Shortcomings. Camb. J. Reg. Econ. Soc. 2015, 8, 131-136. [CrossRef]

28. Rochet, C. Smart Cities: Reality or Fiction; Wiley: London, UK; Hoboken, NJ, USA, 2018.

29. Allwinkle, S.; Cruickshank, P. Creating Smart-Er Cities: An Overview. J. Urban Technol. 2011, 18, 1-16. [CrossRef]

30. Caragliu, A.; del Bo, C.; Nijkamp, P. Smart Cities in Europe. J. Urban Technol. 2011, 18, 65-82. [CrossRef]

31. Kuk, G.; Janssen, M. The Business Models and Information Architectures of Smart Cities. J. Urban Technol. 2011, 18, 39-52. [CrossRef]

32. Schaffers, H.; Komninos, N.; Pallot, M.; Trousse, B.; Nilsson, M.; Oliveira, A. LNCS 6656-Smart Cities and the Future Internet: Towards Cooperation Frameworks for Open Innovation. In Future Internet Assembly LNCS; Springer: Berlin/Heidelberg, Germany, 2011; pp. 431-446. [CrossRef]

33. Deakin, M. Smart Cities: Governing, Modelling and Analysing the Transition; Routledge: London, UK, 2013. [CrossRef]

34. Miciukiewicz, K.; Vigar, G. Mobility and Social Cohesion in the Splintered City: Challenging Technocentric Transport Research and Policy-Making Practices. Urban Stud. 2012, 49, 1941-1957. [CrossRef]

35. Jensen, O.B.; Richardson, T. Making European Space: Mobility, Power and Territorial Identity; Routledge: London, UK, 2003.

36. Canzler, W.; Knie, A. Mobility in the Age of Digital Modernity: Why the Private Car Is Losing Its Significance, Intermodal Transport Is Winning and Why Digitalisation Is the Key. Appl. Mobil. 2016, 1, 56-67. [CrossRef]

37. Urry, J. The 'System' of Automobility. Theory Cult. Soc. 2004, 21, 25-39. [CrossRef]

38. Hajer, M.; Kesselring, S. Democracy in the Risk Society? Learning from the New Politics of Mobility in Munich. Environ. Politics 1999, 8, 1-23. [CrossRef]

39. Kesselring, S. Mobile Politik: Ein Soziologischer Blick Auf Verkehrspolitik in München; Univ., Diss-München, 2000; Sigma: Berlin, Germany, 2001.

40. Freudendal-Pedersen, M.; Hartmann-Petersen, K.; Kjærulff, A.A.; Nielsen, L.D. Interactive Environmental Planning: Creating Utopias and Storylines within a Mobilities Planning Project. J. Environ. Plan. Manag. 2017, 60, 941-958. [CrossRef]

41. Castells, M. The Networked City. In The Social Fabric of the Networked City; Pflieger, G., Pattaroni, L., Jemelin, C., Kaufmann, V., Eds.; Routledge: Oxford, UK, 2008; pp. v-xiii.

42. Graham, S. The Cybercities Reader; Graham, S., Ed.; Routledge: London, UK, 2004. [CrossRef]

43. Neal, Z.P. The Connected City: How Networks Are Shaping the Modern Metropolis; Routledge: New York, NY, USA; London, UK, 2013.

44. Bakici, T.; Almirall, E.; Wareham, J. A Smart City Initiative: The Case of Barcelona. J. Knowl. Econ. 2013, 4, 135-148. [CrossRef]

45. Paskaleva, K.A. The Smart City: A Nexus for Open Innovation? Intell. Build. Int. 2011, 3, 153-171. [CrossRef]

46. Rat-Fischer, C.; Rapp, F.; Meidl, P.; Lewald, N. Smart City: Energy Efficiency in a New Scope. In Resilient Cities 2-Cities and Adaptation to Climate Change-Proceedings of the Global Forum 2011; Otto-Zimmermann, K., Ed.; Springer International: Munich, Germany, 2012; pp. 119-124. 
47. Streitz, N. Smart Cities, Ambient Intelligence and Universal Access. In Universal Access in HCI, Part III; Stephanidis, C., Ed.; Springer: Berlin/Heidelberg, Germany, 2011; pp. 225-432. [CrossRef]

48. Hollands, R.G. Critical Interventions into the Corporate Smart City. Camb. J. Reg. Econ. Soc. 2014, 8, 61-77. [CrossRef]

49. Hollands, R.G. Will the Real Smart City Please Stand Up? City 2008, 12, 303-320. [CrossRef]

50. Vanolo, A. Smartmentality: The Smart City as Disciplinary Strategy. Urban Stud. 2014, 51, 883-898. [CrossRef]

51. Vanolo, A. The Image of the Creative City: Some Reflections on Urban Branding in Turin. Cities 2008, 5, 370-382. [CrossRef]

52. Bell, S. System City: Urban Amplification and Inefficient Engineering. In Urban Constellations; Gandy, M., Ed.; JOVIS: Berlin, Germany, 2011; pp. 71-74.

53. Wyly, E. The City of Cognitive-Cultural Capitalism. City 2013, 17, 387-394. [CrossRef]

54. Greenfield, A. Against the Smart City (The City Is Here for You to Use); DO Projects: New York, NY, USA, 2013.

55. Townsend, A.M. Smart Cities: Big Data, Civic Hackers, and the Quest for a New Utopia; W.W. Norton and Company: New York, NY, USA, 2013.

56. Kitchin, R. The Real-Time City? Big Data and Smart Urbanism. GeoJournal 2014, 79, 1-14. [CrossRef]

57. Graham, S.; Marvin, S. Splintering Urbanism: Networked Infrastructures, Technological Mobilities and the Urban Condition; Routledge: London, UK, 2001.

58. Rutherford, J. Rethinking the Relational Socio-Technical Materialities of Cities and ICTs. J. Urban Technol. 2011, 18, 21-33. [CrossRef]

59. Sennett, R. No One Likes a City That's Too Smart. The Guardian, 4 December 2012; p. 1.

60. Söderström, O.; Paasche, T.; Klauser, F. Smart Cities as Corporate Storytelling. City 2014, 18, 307-320. [CrossRef]

61. Hajer, M. On Being Smart about Cities: Seven Considerations for a New Urban Planning and Design. In Untamed Urbanism; Allen, A., Lampis, A., Swilling, M., Eds.; Routledge: Oxon, NY, USA, 2016; pp. 50-63.

62. Hajer, M.; Nilsson, M.; Raworth, K.; Bakker, P.; Berkhout, F.; de Boer, Y.; Rockström, J.; Ludwig, K.; Kok, M. Beyond Cockpit-Ism: Four Insights to Enhance the Transformative Potential of the Sustainable Development Goals. Sustainability 2015, 7, 1651-1660. [CrossRef]

63. Hajer, M.A.; Pelzer, P. 2050-An Energetic Odyssey: Understanding 'Techniques of Futuring' in the Transition towards Renewable Energy. Energy Res. Soc. Sci. 2018, 44, 222-231. [CrossRef]

64. Freudendal-Pedersen, M.; Kesselring, S. Mobilities, Futures and the City. Repositioning Discourses-Changing Perspectives—Rethinking Policies. Mobilities 2016, 11, 573-584. [CrossRef]

65. Wolfram, M. Deconstructing Smart Cities: An Intertextual Reaing of Concepts and Practices for Integrated Urban and ICT Development. In Real Corp 2012; Tagungsband: Berlin, Germany, 2012; pp. 171-181. [CrossRef]

66. Boltanski, L.; Thévenot, L. On Justification: Economies of Worth; Princeton University Press: Princeton, NJ, USA, 2006.

67. Bauman, Z.; Donskis, L. Moral Blindness: The Loss of Sensitivity in Liquid Modernity; Polity Press: Cambridge, UK, 2013.

68. Sandercock, L. Towards Cosmopolis. Planning for Multicultural Cities; Wiley: Chichester, UK, 1998.

69. Fischer, F.; Gottweis, H. The Argumentative Turn Revistited. In The Argumentative Turn Revisited; Fischer, F., Gottweis, H., Eds.; Duke University Press: Durham, UK, 2012; pp. 1-27.

70. Hajer, M.A. Doing Discourse Analysis: Coalitions, Practices, Meaning. In Words Matter in Policy and Planning; KNAG/NETHUR: Utrecht, The Netherlands, 2006; pp. 13-20.

71. Hajer, M.; Dassen, T. Visualizing the Challenge for 21st Century Urbanism; NAI010 Publishers: Rotterdam, The Netherlands, 2014.

72. Harvey, D. Rebel Cities_From the Right to the City to the Urban Revolution; Verso: London, UK; New York, NY, USA, 2012.

73. Urry, J. What Is the Future? Polity Press: Cambridge, UK; Malden, MA, USA, 2016.

74. Hajer, M. The Politics of Environmental Discourse. Ecological Modernization and the Policy Process; Clarendon Press: Oxford, UK, 1995.

75. Hajer, M. Discourse Coalitions and the Institutionalization of Prctice: The Case of Acid Rain in Britain. In The Argumentative Turn in Policy Analysis and Planning; Fischer, F., Forester, J., Eds.; Duke University Press: London, UK, 1993; pp. 43-76. 
76. Tschoerner-Budde, C. Sustainable Mobility in Munich: Exploring the Role of Discourse in Policy Change; Springer Fachmedien Wiesbaden: Weisbaden, Germany, 2019.

77. Beck, U.; Kesselring, S. Mobilitätspolitik unter den Bedingungen der Reflexiven Modernisierung. Eine Untersuchung der Mobilitätspolitik in der Landeshauptstadt München. Final Report to the German Ministry of Research; unpublished manuscript; München, Germany, 1998.

78. Kesselring, S.; Moritz, F.; Petzel, W.; Vogl, G. Kooperative Mobilitätspolitik: Theoretische, Empirische Und Praktische Perspektiven Am Beispiel München Und Frankfurt, Rhein-Main; IMU; IMU-Inst: München, Germany, 2003.

79. Nielsen, L.D.; Gudmundson, H.; Kromann-Vestergaard, L.; Freudendal-Pedersen, M.; Hartmann-Petersen, K.; Puggard, A. Formel M Demonstration OG Forankring AF Mobility Management 2011-2014; Roskilde University: Albertslund, Denmark, 2014.

80. Kesselring, S.; Tschoerner, C. The Deliberative Practice of Vision Mobility 2050: Vision-Making for Sustainable Mobility in the Region of Munich? Transp. Res. Procedia 2016, 19, 380-391. [CrossRef]

81. Servou, E. Who Talks about Electric Mobility and How? A Discursive Analysis of Electric Mobility in Munich; Aalborg University: Aalborg, Denmark, 2016.

82. Wulfhorst, G.; Kenworthy, J.; Kesselring, S.; Lanzendorf, M. Perspectives on Mobility Cultures in Megacities. In Institute for Mobility Research. Lecture Notes in Mobility. Megacity Mobility Culture: How Cities Move on in a Diverse World; Wulfhorst, G., Kenworthy, J., Kesselring, S., Lanzendorf, M., Eds.; Springer: Berlin/Heidelberg, Germany, 2013; pp. 243-258.

83. Kesselring, S.; Wulfhorst, G. Perspectives on Sustainable Mobility in Metropolitan Regions: Shaping Mobility Cultures. In Studien zur Mobilitäts- und Verkehrsforschung. Sustainable Mobility in Metropolitan Regions: Insights from Interdisciplinary Research for Practice Application; Wulfhorst, G., Klug, S., Eds.; Springer Fachmedien Wiesbaden: Wiesbaden, Germany, 2016; pp. 201-222.

84. Iwer, F. Ökologischer Umbau Der Automobilindustrie: Die Neue Herausforderung. In Gute Arbeit: Ausgabe 2018. Ökologie der Arbeit: Impulse für Einen Nachhaltigen Umbau; Schröder, L., Urban, H.-J., Eds.; Bund Verlag: Frankfurt, Germany, 2018; pp. 85-103.

85. Jürgens, U.; Krzywdzinski, M.; Burgess, P. The New Worlds of Work: Varieties of Work in Car Factories in the BRIC Countries; Oxford University Press: Oxford, UK, 2016.

86. Kröger, F. Automated Driving in Its Social, Historical and Cultural Contexts. In Autonomous Driving: Technical, Legal and Social Aspects; Maurer, M., Gerdes, J.C., Lenz, B., Winner, H., Eds.; Springer: Berlin/Heidelberg, Germany, 2016; pp. 41-68. [CrossRef]

87. Dennis, K.; Urry, J. After the Car; Polity: Cambridge, UK, 2009.

88. Lamon, P.; Kolski, S.; Siegwart, R. The SmartTer-a Vehicle for Fully Autonomous Navigation and Mapping in Outdoor Environments. In Proceedings of the 9th International Conference Climbing Walknig Robots Support Technologies Mobile Machines, New York, NY, USA, 4-7 January 2006.

89. Infrastruktur, B. Forschungsprogramm Zur Automatisierung Und Vernetzung Im Straßenverkehr; Springer International: Munich, Germany, 2016.

90. Kreisverwaltungsreferat, R. Automatisiertes Fahren Und Vernetzung Des Straßenverkehrs Im Städtischen Kontext Pilotstadt München: Teilnahme Der Landeshauptstadt München Am Kooperativen Forschungsprojekt EASYRIDE; Unveröff. Msk.: München, Germany, 2018.

91. Kesselring, S. Planning in Motion: The New Politics of Mobility in Munich. In Understanding Mobilities for Designing Contemporary Cities; Pucci, P., Colleoni, M., Eds.; Springer: Cham, Switzerland, 2016; pp. 67-85.

92. Commission, E. Gear 2030 Discussion Paper. Roadmap on Highly Automated Vehicles; CIRCABC: Brussels, Belgium, 2016. [CrossRef]

93. Infrastructure, F. Strategy for Automated and Connected Driving; Federal Ministry of Transport and Digital Infrastructure: Berlin, Geermany, 2015.

94. Kesselring, S. The Mobile Risk Society. In Tracing Mobilities; Canzler, W., Kaufmann, V., Kesselring, S., Eds.; Ashgate: Aldershot and Burlington, ON, Canada, 2008; pp. 77-102.

95. Telotte, J.P. Mouse Machine: Disney and Technology; University of Illinois Press: Champaign, IL, USA, 2008.

96. Schwarz, M.; Thomsen, M. Divided We Stand: Redefining Politics, Technology and Social Choice; Harvester Wheatsheaf: New York, NY, USA, 1990.

97. Lipson, H.; Kurman, M. Driverless: Intelligent Cars and the Road Ahead; MIT Press: Cambridge, MA, USA, 2016. 
98. Latour, B. Reassembling the Social-An Introduction to Actor-Network-Theory; Oxford University Press: Oxford, UK, 2005.

99. Latour, B. ARAMIS or the Love of Technology; Harvard Univ. Press: Cambridge, UK, 1996.

100. Firnkorn, J.; Müller, M. Selling Mobility Instead of Cars: New Business Strategies of Automakers and the Impact on Private Vehicle Holding. Bus. Strateg. Environ. 2012, 21, 264-280. [CrossRef]

101. Diez, W. Wohin Steuert Die Deutsche Automobilindustrie? De Gruyter Oldenbourg: Berlin, Geermany, 2018.

102. Theodore, N.; Peck, J.; Brenner, N. Neoliberal Urbanism: Cities and the Rule of Markets. In The New Blackwell Companion to the City; Wiley-Blackwell: Hoboken, NJ, USA, 2012; pp. 15-25. [CrossRef]

103. Tyfield, D. Liberalism 2.0 and the Rise of China Global Crisis and Innovation; Routledge: London, UK, 2018.

104. Elliott, A. Automated Mobilities: From Weaponized Drones to Killer Bots. J. Sociol. 2018, 1-17. [CrossRef]

105. Allmendinger, P.; Haughton, G. Post-Political Spatial Planning in England: A Crisis of Consensus? Trans. Inst. Br. Geogr. 2012, 37, 89-103. [CrossRef]

106. Harvey, D. The Condition of PostModernity; Blackwell Publishers: Cambridge, UK, 1989.

107. Friedrich, E.; Lenz, B. Societal and Individual Acceptance of Automated Driving. In Automated Driving: Technical, Legal and Social Aspects; Maurer, M., Lenz, B., Winner, H., Gerdes, C.J., Eds.; Springer: Berlin/Heidelberg, Germany, 2016; pp. 621-640.

108. Kellerman, A. Automated and Autonomous Spatial Mobilities; Transport, Mobilities and Spatial Change; Edward Elgar Publishing: Cheltenham, UK, 2018.

(C) 2019 by the authors. Licensee MDPI, Basel, Switzerland. This article is an open access article distributed under the terms and conditions of the Creative Commons Attribution (CC BY) license (http://creativecommons.org/licenses/by/4.0/). 